\title{
Innovative approach of drills acquisition using electrical current. A case study
}

\author{
Raluca Daicu*, Valentin Diţu, and Gheorghe Oancea
}

Transilvania University of Braşov, Department of Manufacturing Engineering, Mihai Viteazu No. 5, Braşov, Romania

\begin{abstract}
During the process of drilling metals there are used cutting tools that can be acquisitioned directly from the producers, from distributors or from supermarkets. Because the offer is varied and there are different producers, the acquisition must be made after an economical analysis that includes experimental tests. The paper presents an innovative methodology of drills acquisition based on electrical current at cutting process. The researches were developed using HS 6-5-2 steel drills of 8 $\mathrm{mm}$ diameter, in two batches, acquisitioned from two different suppliers, at different prices. The drills were tested on 1C45 material using the same values for cutting parameters and because the electrical current at cutting is sensible to any imperfection of the tools, the batches were analysed from qualitative and economical point of view.
\end{abstract}

\section{Introduction}

Due to high frequency of reaming processing, the correct acquisition of cutting tools can lead to significant economies in industry and it also guides the small business to avoid bad quality tools that can be found, for example in supermarkets at lower prices. The supermarkets do not give any information about the tool life of drills in order to make a quality/price ratio. For this reason it is opportune to analyse different brands of drills acquisitioned from different sources.

An approach of the outlined issue is presented in other researches [1], where it was used the electrical current at cutting to analyse the quality of drills. Previous researches [2-11] conducted to the fact that the state of a cutting edge can be appreciated by the value of cutting electrical current voltage, because the higher this value is, the higher the initial temperature is.

The previous researches developed by the authors demonstrate a connection between the electrical current at cutting and the quality of the cutting edges, by microscopically examination of the drills edges and identifying causes of the high electrical current voltage [1]. The conclusion was that the electrical current is sensible to any imperfection of the drill edge. In this research is used the electrical current at cutting to develop an innovative acquisition methodology for drills.

\footnotetext{
*Corresponding author: raluca.daicu@unitbv.ro
} 


\section{Qualitative analysis of two drill batches, from two suppliers, using electrical current at cutting}

There were acquisitioned two HS 6-5-2 steel drill batches, from two different suppliers, at different prices, each batch having 10 drills.

For the qualitative analysis of the two batches it will be used the voltage of electrical current at cutting. The experimental steps are:

- voltage measurement of the electrical current at cutting, for each drill, with the installation presented in Figure 1;

- microscopic visualisation of drill edges to obtain additional information about the connection between the electrical current voltage at drilling and the state of the cutting edge;

- for the drill with the lowest voltage and for the drill with the highest voltage there will be done tool life tests;

- tool life estimation for all the drills from the batch.

The experiments were done on 1C45 material which has the following chemical composition: $\mathrm{C}=0.45 \%, \mathrm{Si}=0.22 \%, \mathrm{Mn}=0.56 \%, \mathrm{P}=0.025 \%, \mathrm{~S}=0.034$. The tensile strength of $1 \mathrm{C} 45$ steel is $660 \mathrm{MPa}\left(66 \mathrm{daN} / \mathrm{mm}^{2}\right)$ and the hardness is $224 \mathrm{HB}$.

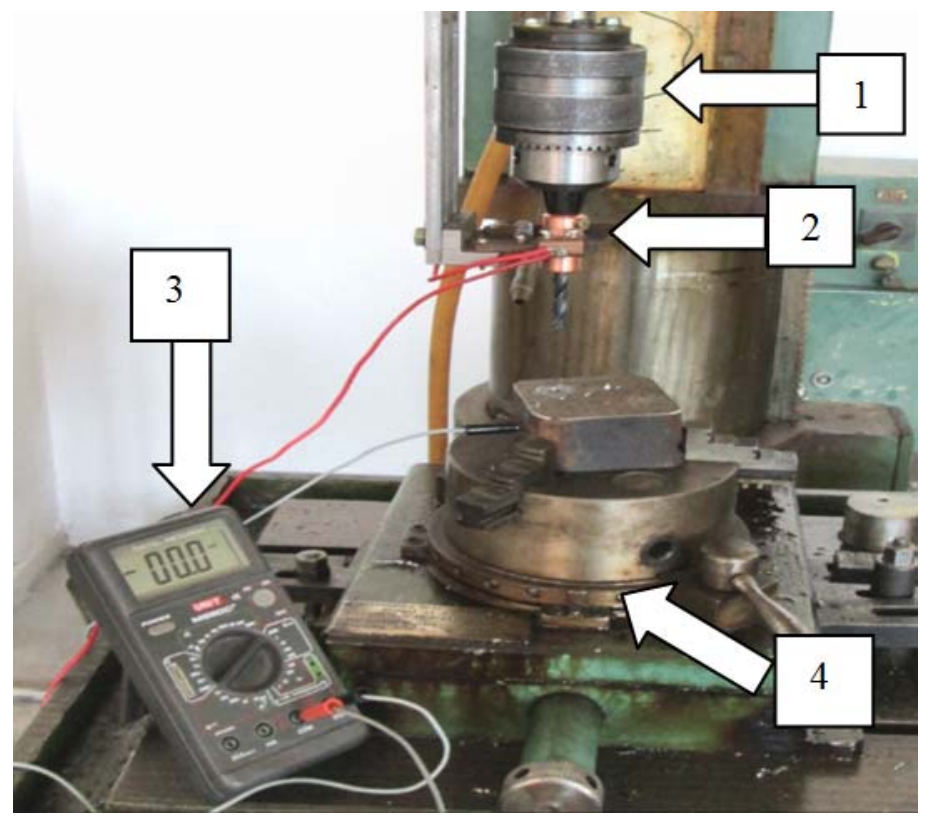

Fig. 1. Experimental stand used in measuring process of the electrical current at normal drilling.

The experimental stand is composed of mandrel for fixing the drill (1), collector brushes (2), measuring instrument for electrical current voltage at cutting (3), and clamping device for multiple drillings (4).

The tests made for batch I from the first supplier and for batch II from the second supplier are centralized in Table 1.

Based on the obtained results shown in Table 1, it was generated the Table 2 that shows, comparatively, for the two batches, the number of drills that had the same value of the electrical current voltage, and also the lowest and highest values for each batch. 
Table 1. Obtained values for cutting electrical current voltage at drilling $1 \mathrm{C} 45$ steel with drills from batch I and batch II

\begin{tabular}{|c|c|c|c|c|c|}
\hline No. of drill & $\begin{array}{c}\text { Drill } \\
\text { diameter } \\
{[\mathrm{mm}]}\end{array}$ & $\begin{array}{c}\text { Spindle } \\
\text { speed } \\
\text { [rev/min] }\end{array}$ & $\begin{array}{c}\text { Feed } \\
{[\mathrm{mm} / \mathrm{rev}]}\end{array}$ & $\begin{array}{c}\text { Voltage "UI" } \\
\text { for drills } \\
\text { from batch I } \\
{[\mathrm{mV}]}\end{array}$ & $\begin{array}{c}\text { Voltage "UII" } \\
\text { for drills } \\
\text { from batch II } \\
{[\mathrm{mV}]}\end{array}$ \\
\hline 1 & \multirow{10}{*}{8} & \multirow{10}{*}{560} & \multirow{10}{*}{0.25} & 0.4 & 0.4 \\
\hline 2 & & & & 0.7 & 0.3 \\
\hline 3 & & & & 0.6 & 0.4 \\
\hline 4 & & & & 0.6 & 0.6 \\
\hline 5 & & & & 0.3 & 0.3 \\
\hline 6 & & & & 0.3 & 0.4 \\
\hline 7 & & & & 0.5 & 0.5 \\
\hline 8 & & & & 0.4 & 0.3 \\
\hline 9 & & & & 0.2 & 0.2 \\
\hline 10 & & & & 0.4 & 0.3 \\
\hline
\end{tabular}

Table 2. Number of drills from batch I and II that had the same value of the electrical current voltage

\begin{tabular}{|c|c|c|c|}
\hline $\begin{array}{c}\text { Crt. } \\
\text { No. }\end{array}$ & $\begin{array}{c}\text { Electrical current } \\
\text { voltage } \\
\text { U [mV] }\end{array}$ & $\begin{array}{c}\text { No. of drills } \\
\text { from batch I }\end{array}$ & $\begin{array}{c}\text { No. of drills } \\
\text { from batch II }\end{array}$ \\
\hline 1 & 0.2 & 1 & 1 \\
\hline 2 & 0.3 & 1 & 4 \\
\hline 3 & 0.4 & 3 & 3 \\
\hline 4 & 0.5 & 2 & 1 \\
\hline 5 & 0.6 & 2 & 1 \\
\hline 6 & 0.7 & 1 & 0 \\
\hline \multicolumn{2}{|c|}{ Total } & 10 & 10 \\
\hline
\end{tabular}

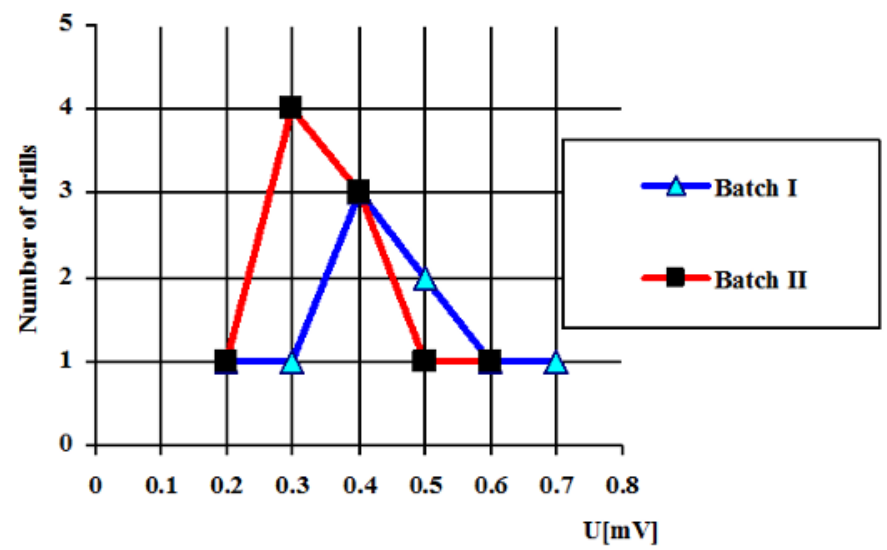

Fig. 2. Number of drills from each batch that had the same value of the electrical current voltage. 
From Figure 2 where the data from Table 2 are represented, it can be observed that the batch II has the highest number of drills with voltage of $0.3 \mathrm{mV}$ (4 drills) and batch I has the highest number of drills with voltage of $0.4 \mathrm{mV}$. Also, it can be observed that the difference between the highest and the lowest voltage is smaller for batch II, and this mean that the process of drills manufacturing is better handled.
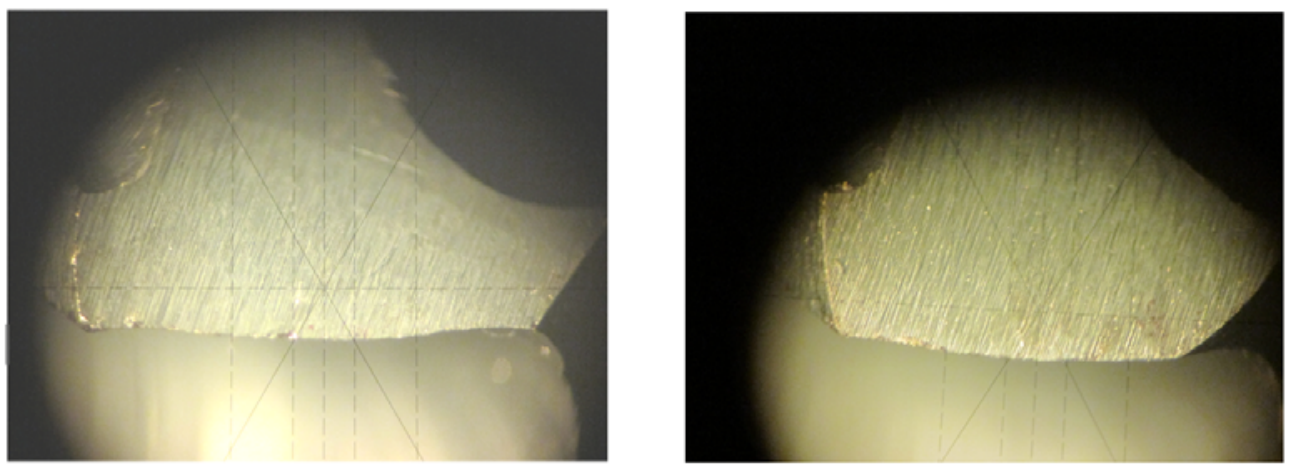

Fig. 3. Microscopic image of cutting edges at drill no. 9 from batch I.
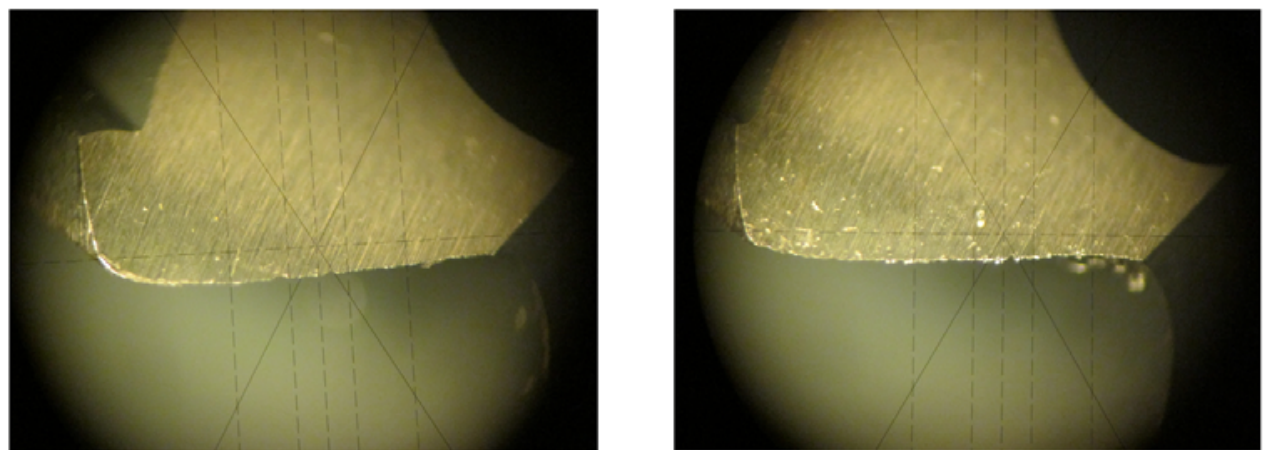

Fig. 4. Microscopic image of cutting edges at drill no. 9 from batch II.
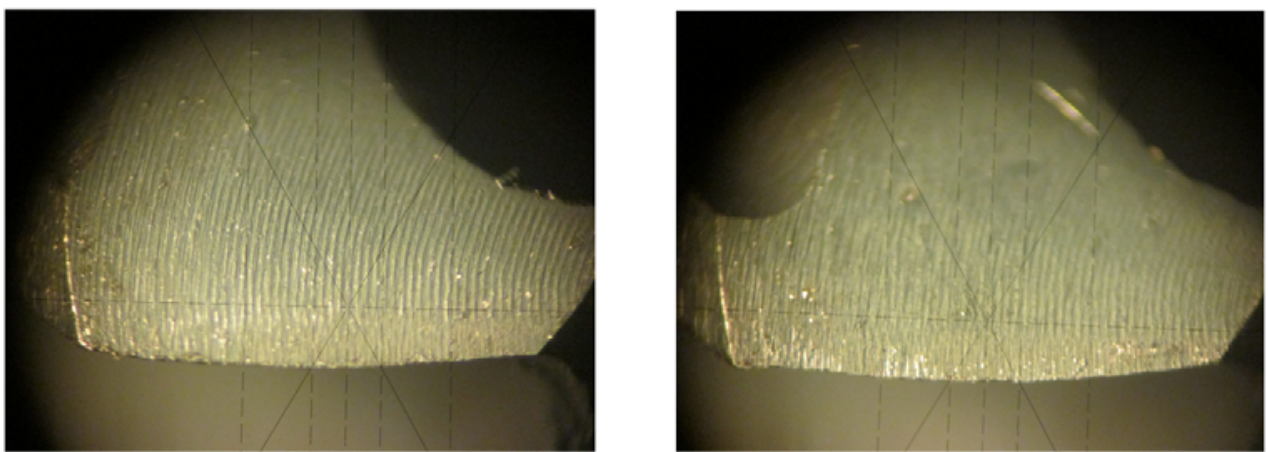

Fig. 5. Microscopic image of cutting edges at drill no. 2 from batch I.

The lowest value of voltage, $0.2 \mathrm{mV}$, was obtained with drills no. 9 from the two batches. In Figure 3 is presented the microscopic image of drill no. 9 from batch I, and in Figure 4 is presented the image of drill no. 9 from batch II. It can be observed that both of them have a very good state of the cutting edges. 
The highest value of the voltage, $0.7 \mathrm{mV}$, was given by drill no. 2 from batch $\mathrm{I}$, and the voltage of $0.6 \mathrm{mV}$ was obtained for drill no. 4 from batch II. The Figures 5 and 6 show the state of the cutting edges for these two drills.
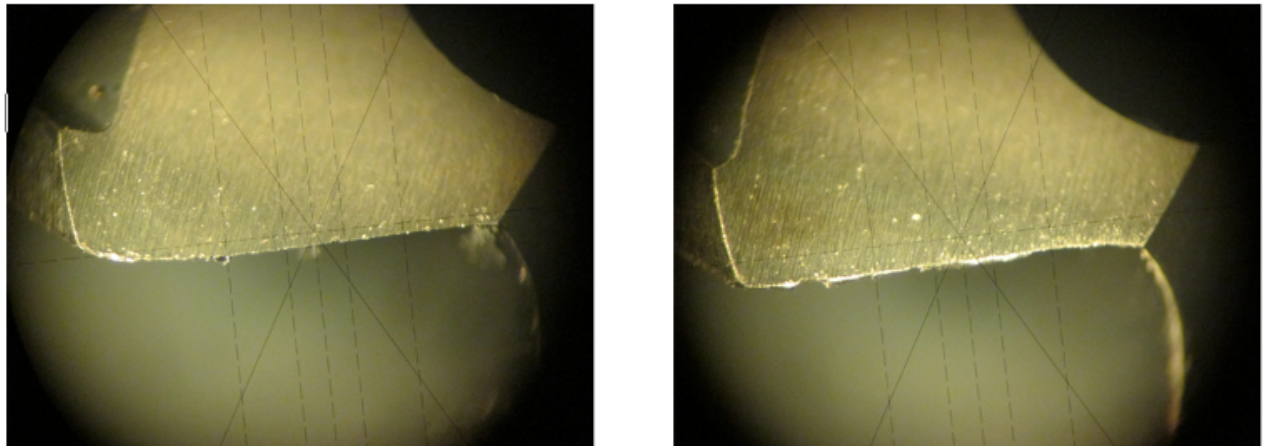

Fig. 6. Microscopic image of cutting edges at drill no. 4 from batch II.

From these microscopic images it can be observed that the high voltage of $0.7 \mathrm{mV}$ (Figure 5) was obtained due to the high roughness of the land surfaces fact that lead to imperfections on the cutting lips. The voltage of $0.6 \mathrm{mV}$ (Figure 6) was due to the notches from one cutting lip, and a higher roughness on the land surfaces than drill no. 9 from same batch (Figure 4).

\section{Economical analysis of two drill batches}

The economical analysis of the two batches starts from the qualitative analysis presented in section 2. The steps for the economical analysis are:

- tests for tool life will be made on the drills from the two batches, on the 1C45 material, until it appears a $0.4 \mathrm{~mm}$ wear at corners;

- tool life for each drill will be estimated based on the voltage of the electrical current;

- total machined length with all 10 drills from a batch has to be calculated;

- acquisition cost of the drill batch is divided by the total machined length with all drills from the batch and it will result the average cost to process $1 \mathrm{~mm}$ length;

- obtained value for this indicator for the two analysed batches will be compared and a decision will be taken.

Table 3. Tool life tests for the drills from each batch

\begin{tabular}{|c|c|c|c|c|c|c|c|}
\hline $\begin{array}{l}\text { Drill } \\
\text { No. }\end{array}$ & $\begin{array}{c}\text { Drill } \\
\text { diameter } \\
{[\mathrm{mm}]}\end{array}$ & $\begin{array}{c}\text { Spindle } \\
\text { speed } \\
\text { [rev/min] }\end{array}$ & $\begin{array}{c}\text { Feed } \\
{[\mathrm{mm} / \mathrm{rev}]}\end{array}$ & $\begin{array}{c}\text { Voltage } \\
\text { "UI" for } \\
\text { batch I } \\
{[\mathrm{mV}]}\end{array}$ & $\begin{array}{c}\text { Machined } \\
\text { length } \\
\text { batch I } \\
\text { [mm] }\end{array}$ & $\begin{array}{c}\text { Voltage } \\
\text { “UII" for } \\
\text { batch II } \\
{[\mathrm{mV}]}\end{array}$ & $\begin{array}{c}\text { Machined } \\
\text { length } \\
\text { batch II } \\
\text { [mm] }\end{array}$ \\
\hline 1 & \multirow{10}{*}{8} & \multirow{10}{*}{560} & \multirow{10}{*}{0.25} & 0.4 & 168 & 0.4 & 171 \\
\hline 2 & & & & 0.7 & 17 & 0.3 & 231 \\
\hline 3 & & & & 0.6 & 54 & 0.4 & 228 \\
\hline 4 & & & & 0.6 & 56 & 0.6 & 63 \\
\hline 5 & & & & 0.3 & 224 & 0.3 & 225 \\
\hline 6 & & & & 0.3 & 226 & 0.4 & 166 \\
\hline 7 & & & & 0.5 & 112 & 0.5 & 115 \\
\hline 8 & & & & 0.4 & 163 & 0.3 & 224 \\
\hline 9 & & & & 0.2 & 282 & 0.2 & 285 \\
\hline 10 & & & & 0.4 & 166 & 0.3 & 230 \\
\hline \multicolumn{5}{|c|}{ Total } & 1468 & & 1938 \\
\hline
\end{tabular}


In Table 3 are presented the results obtained for tool life test for all drills from each batch. The admissible wear at the corner of the cutting lip was $0.4 \mathrm{~mm}$ (not $0.6 \mathrm{~mm}$ as recommended) in order to shorten the time for experiments and reduce the material consumption.

The first batch was acquisitioned with 11.1 EUR and the second batch with 19.15 EUR. The price per mm length for the first batch will be 11.1 EUR divided to $1468 \mathrm{~mm}$, thus the result is $0.0075 \mathrm{EUR} / \mathrm{mm}$. For the second batch, the price per $\mathrm{mm}$ length is 0.0098 EUR/mm, obtained from the drills price (19.15 EUR) and the associated machined length (1938 mm).

\section{Conclusions}

Due to the experiments, the next conclusions are drawn:

- from the qualitative analysis resulted that the drills from the second batch acquisitioned from the second supplier, had a better quality than the drills from the first batch;

- from the economical analysis resulted that for personal and occasional use, it is better to acquire drills from the first supplier, because they are cheaper;

- for industrial purposes, it resulted that is better to acquire drills from the second supplier, because even if the cost per mm length is higher, the quality of the processed reaming is better, due to a good state of the cutting edges, fact observed also from microscopic analysis;

- electrical current at cutting is sensible to any imperfection of the cutting edge and it represents a simple, fast and low cost method to appreciate the quality of a drill batch.

\section{References}

1. V. Diţu, G. Oancea, R. Daicu, MATEC Web Conf. 94, 02005 (2017)

2. V. Diţu, AJME 1, 63 (2008)

3. R. Daicu, G. Oancea, AMM 808, 40 (2015)

4. H. Bagchi, S.K. Basu, Wear 26, 39 (1973)

5. V. Diţu, WSEAS 2, 322 (2009)

6. A.L. Plotnikov, E.G. Krylov, E.M. Frolov, STIN 1, 2 (2009)

7. M. Murata, S. Kurokawa, O. Ohnishi, CSME 79, 2546 (2013)

8. M. Murata, S. Kurokawa, O. Ohnishi, M. Uneda, T. Doi, CSME 6, 958 (2012)

9. H. Hirota, M. Murata, A. Kojima, K. Yanagihara, JSPE 64, 1191 (1998)

10. V. Diţu, AJME 8, 18 (2010)

11. R. Tanaka, A. Hosokawa, K. Yamada, T. Ueda, Proceedings of the Seventh International Conference on Progress of Machining Technology, 786 (2004) 